\title{
Experimental Effects of Lime Application on Aquatic Macrophytes: \\ 1. Growth Response Versus Concentration
}

by William F. James, Harry L. Eakin, and John W. Barko

PURPOSE: The research reported herein investigated the effects of a range of lime (as calcium hydroxide; $\mathrm{Ca}(\mathrm{OH})_{2}$ ) dosage levels on the growth of Sago pondweed in outdoor experimental mesocosms.

BACKGROUND: Lime $\left(\mathrm{CaCO}_{3}\right.$ and $\left.\mathrm{Ca}(\mathrm{OH})_{2}\right)$ application has been used primarily as a lake rehabilitation technique for limiting algal growth by controlling phosphorus availability in the water column and its release from the sediment (Prepas et al. 1990). At supersaturated concentrations, calcium co-precipitates with phosphorus and settles from the water column. As a deposited layer on the sediment, it can adsorb additional phosphorus $(\mathrm{at} \mathrm{pH}>8$ ), preventing it from diffusing into the water column for algal uptake. More recently, researchers have found that lime additions can suppress submersed macrophyte growth as well (Babin et al. 1992, Chambers et al. 2001, Prepas et al. 2001). However, the mode of growth suppression, dosage levels, and exposure time requirements are not entirely known. Since lime application drives the $\mathrm{pH}$ upward, it may stress macrophyte metabolic activities by inducing inorganic carbon limitation for photosynthesis in hardwater systems. Lime additions to aquatic systems at varying concentrations have not resulted in clear macrophyte community responses. For instance, single dosages of lime at modest concentration levels ( $<110 \mathrm{mg} \mathrm{Ca} \mathrm{L}^{-1}$ ) to hardwater lakes were accompanied by control of macrophyte biomass (species) for over a year (Reedyk et al. 2001). However, Chambers et al. (2001) indicated that exposure time, in addition to concentration, might be important in the control of macrophytes in aquatic systems located in the Canadian Great Plains. These findings suggest that lime application may be a very promising technique for integrated control of both macrophyte and algal production in eutrophic hardwater systems. More information is needed regarding the mode of action, dosage requirements, and impacts on different aquatic macrophyte species in order to develop sound integrated management and control strategies using lime.

The objectives in Phase 1 of this research were to examine the effects of different lime dosages on the growth of a test plant, Sago pondweed, in experimentally controlled mesocosms.

METHODS: Experimental lime application rates and the study design are shown in Table 1. A lime concentration range between 0 and $1000 \mathrm{mg} \mathrm{L}^{-1}$ was chosen to overlap and extend beyond concentration ranges that have been used in field experiments (typically 10 to $275 \mathrm{mg} \mathrm{L}^{-1}$ (Prepas et al. 2001, Reedyk et al. 2001, Chambers et al. 2001, Rattei 2004)). Sago pondweed (Stuckenia pectinatus (L.) Boerner) was used as the experimental macrophyte in the lime application studies. Commercially obtained propagules (Kester's W.F.G. Nurseries, Omro, Wisconsin) were germinated for 1 week prior to initiation of the experiment. One sprouted plant was transplanted into each polyethylene container (16 cm wide by $16 \mathrm{~cm}$ deep by $22 \mathrm{~cm}$ high) filled with homogenized sediment to a depth of $10 \mathrm{~cm}$. The sediment was collected from the littoral zone of nearby Eau Galle Reservoir, Wisconsin (moisture content $=71$ percent; bulk density $=0.29 \mathrm{~g} \mathrm{~L}^{-1}$; total sediment $\mathrm{N}=$ $4.702 \mathrm{mg} \mathrm{g}^{-1}$; porewater ammonium- $\mathrm{N}=5.750 \mathrm{mg} \mathrm{L}^{-1}$; total sediment $\mathrm{P}=0.971 \mathrm{mg} \mathrm{g}^{-1}$; porewater 


\section{Table 1}

Experimental Treatments and Lime Application Concentrations

\begin{tabular}{|l|l|c|c||}
\hline & & \multicolumn{2}{|c|}{ Lime Concentration } \\
\cline { 3 - 4 } Treatment & Plant Replicates per Mesocosm & $\left(\mathbf{m g ~ L}^{-1}\right)$ & $\left(\mathbf{m g ~ m}^{-2}\right)$ \\
\hline 1 & 6 & 0 & 0 \\
\hline 2 & 6 & 250 & 305 \\
\hline 3 & 6 & 500 & 610 \\
\hline 4 & 6 & 1000 & 1220 \\
\hline
\end{tabular}

$\mathrm{P}=0.359 \mathrm{mg} \mathrm{L}^{-1}$ ). Six replicate containers were planted for each treatment for a total of 24 containers. The replicate planted containers were incubated in each of four clear fiberglass mesocosms (i.e., one mesocosm per treatment; 1.2-m diameter by 1.2-m height; 1400-L capacity) that were deployed in a larger outdoor pool (4.6-m diameter by 1.2-m deep). The pool served as a water bath to moderate the temperature of the mesocosms during the summer. All mesocosms were filled with tap water prior to the start of the experiment $\left(\mathrm{Ca}=57 \mathrm{mg} \bullet \mathrm{L}^{-1}\right.$; Conductivity $=422 \mu \mathrm{S}$; $\mathrm{Mg}=28 \mathrm{mg} \cdot \mathrm{L}^{-1} ; \mathrm{NO}_{2} \mathrm{NO}_{3}-\mathrm{N}=0.2 \mathrm{mg} \cdot \mathrm{L}^{-1} ; \mathrm{K}=0.8 \mathrm{mg} \cdot \mathrm{L}^{-1} ; \mathrm{Na}=1.6 \mathrm{mg} \cdot \mathrm{L}^{-1} ; \mathrm{SO}_{4}=21 \mathrm{mg} \cdot \mathrm{L}^{-}$ ; $\mathrm{pH}=7.8$ ). Circulation pumps (Beckett Versa Gold G90AG; $0.34 \mathrm{~m}^{3} \mathrm{~min}^{-1}$ ) provided moderate water circulation in each tank during the entire study.

The plants were allowed to grow in the outdoor mesocosm facility for 45 days prior to lime application. Commercially obtained lime (as $\left.\mathrm{Ca}(\mathrm{OH})_{2}\right)$ was applied as a slurry to experimental mesocosms by mixing the appropriate dry powder mass (as grams of $\mathrm{Ca}(\mathrm{OH})_{2}$ ) for each intended concentration with $8 \mathrm{~L}$ of tap water, then dispersing it evenly over the surface of the mesocosms. The plants were allowed to grow for an additional 17 days after lime application before harvesting. The study was conducted between 13 June and 14 August 2003.

Shoot and root fresh and dry biomass were determined for each plant container at the end of the study. For shoot biomass, a 10-cm sprig was removed, weighted, and frozen for analysis of leaf chlorophyll. The remaining shoot material was briefly soaked in a 1-N hydrochloric acid solution to remove calcium carbonate $\left(\mathrm{Ca}\left(\mathrm{CO}_{3}\right)\right)$ deposits, gently rinsed in tap water, and dried at $90{ }^{\circ} \mathrm{C}$ for dry mass determination. Roots sieved from the sediment were dried for belowground biomass determination (root material was not pretreated with $1 \mathrm{~N} \mathrm{HCl}$ ). Leaf chlorophyll was extracted in a 50:50 solution of DMSO (dimethyl-sulfoxide) and acetone before fluorometric determination (Welschmeyer 1994). Leaf chlorophyll was expressed as $\mathrm{mg} \mathrm{g}^{-1}$ leaf dry mass using correction factors to account for the percentage of fresh mass that represented $\mathrm{Ca}\left(\mathrm{CO}_{3}\right)$ and a $\mathrm{Ca}\left(\mathrm{CO}_{3}\right)$-free fresh mass:dry mass ratio. Shoot biomass at the time of lime application was estimated using Sago pondweed shoot biomass measurements determined in another study over a similar growth period (41 days) and environmental conditions (i.e., the same sediment and water source; James (unpublished)).

Throughout the study, in situ temperature, $\mathrm{pH}$, dissolved oxygen, and conductivity were monitored in each tank at 2- to 3-day intervals using a Hydrolab Surveyor 3 that was calibrated against known buffers and Winkler titrations. Integrated water column samples were collected to determine alkalinity (expressed as mg $\mathrm{CaCO}_{3} \mathrm{~L}^{-1}$ ) as titration with $0.02 \mathrm{~N}$ sulfuric acid to an end-point of $\mathrm{pH}$ 4.5 (American Public Health Association (APHA) 1998). 
RESULTS AND DISCUSSION: Before lime application, mean $\mathrm{pH}$ and alkalinity in the mesocosms were 8.43 ( \pm 0.03 S.E.) and $163 \mathrm{mg} \mathrm{L}^{-1}$ ( \pm 3 S.E.), respectively. Immediately after application of the lime slurries to the mesocosms, the water column became milky white and $\mathrm{pH}$ and alkalinity increased rapidly as a function of lime concentration (Table 2). Over the course of 3 to 5 days, the lime settled as a floc and water column transparency increased to pretreatment levels. Some sedimentation onto the plant material was also evident.

In the mesocosm treated with $250 \mathrm{mg}$ lime $\mathrm{L}^{-1}$, $\mathrm{pH}$ was nearly constant at $\sim 10.5$ over the first week (Figure 1). It then declined in a linear pattern during the next week, approaching control values ( 9.6) by day 17 of treatment. In contrast, alkalinity declined below control levels following lime application and was only $26 \mathrm{mg} \mathrm{L}^{-1}$ at the end of the study, versus a concentration of $140 \mathrm{mg} \mathrm{L}^{-1}$ in the control mesocosm. This pattern indicated that $\mathrm{Ca}$ supersaturation occurred in the 250-mg lime $\mathrm{L}^{-1}$ treatment, causing its precipitation from the water column and a decrease in alkalinity. For the 500- and 1000-mg lime $\mathrm{L}^{-1}$ treatments, $\mathrm{pH}$ increased to 11 or greater over the entire two-week post-treatment period. Alkalinity was nearly constant at $\sim 200 \mathrm{mg} \mathrm{L}^{-1}$ and $600 \mathrm{mg} \mathrm{L}^{-1}$ in the 500-mg lime $\mathrm{L}^{-1}$ and 1000-mg lime $\mathrm{L}^{-1}$ treated mescosms, respectively, and did not decrease despite obviously oversaturated conditions. Overall, a trend of increasing mean $\mathrm{pH}$, relative to controls, was observed as a function of initial lime concentration (Figure 2; ANOVA; Statistical Analysis System (SAS) 1994). Mean post-treatment alkalinity was significantly greater in mesocosms treated with 500-mg lime $\mathrm{L}^{-1}$ and 1000 -mg lime $\mathrm{L}^{-1}$ versus the control mean. However, no significant differences

\section{Table 2 \\ Mean ( \pm 1 standard error) Alkalinity and $\mathrm{pH}$ Immediately After Lime Application}

\begin{tabular}{|c|l|l||}
\hline $\begin{array}{l}\text { Lime Concentration } \\
\left(\mathbf{m g ~ L}^{-1}\right)\end{array}$ & $\mathbf{p H}$ & $\begin{array}{l}\text { Alkalinity } \\
\left(\mathbf{m g ~ L}^{-1}\right)\end{array}$ \\
\hline 0 & $9.21(0.05)$ & $130(10)$ \\
\hline 250 & $10.49(0.10)$ & $134(62)$ \\
\hline 500 & $10.79(0.17)$ & $266(38)$ \\
\hline 1000 & $11.40(0.02)$ & $746(70)$ \\
\hline
\end{tabular}

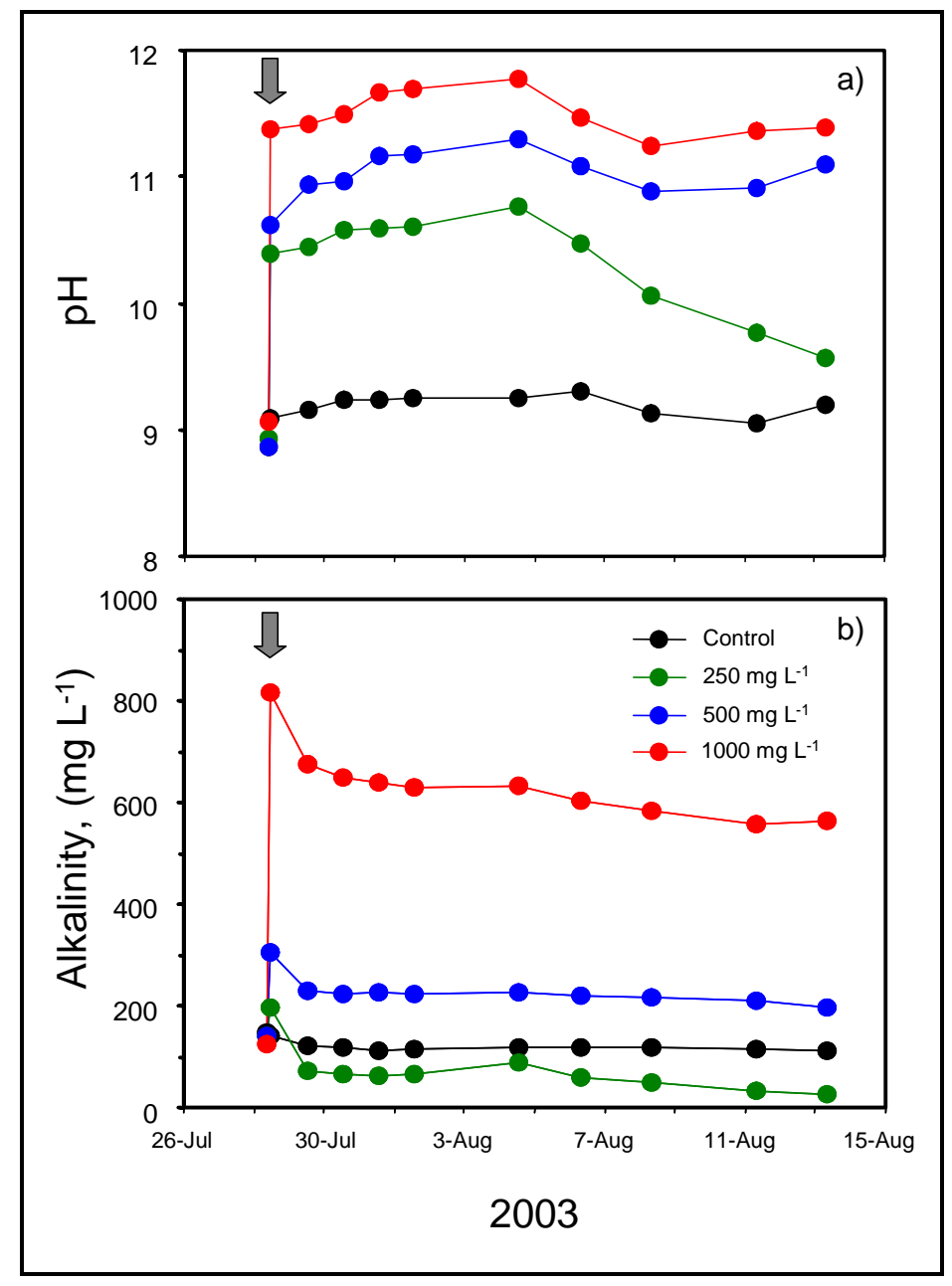

Figure 1. Variations in $\mathrm{pH}$ and alkalinity in the control and treated mesocosms after lime application (arrow denotes the day of treatment) 
were observed in mean post-treatment alkalinity between the control mesocosm and the mesocosm treated with 250-mg lime $\mathrm{L}^{-1}$.

Sago pondweed initiated flowering approximately 4 weeks after germination and had attained a shoot biomass of $4.5 \mathrm{~g} \mathrm{plant}^{-1}( \pm 0.2$ S.E. $)$ prior to lime application (Figure 3). Mean shoot biomass in the untreated control was greater than $7 \mathrm{~g} \mathrm{plant}^{-1}$ at the end of the study, indicating some additional plant growth had occurred in this mesocosm during the lime treatment phase of the study. After lime application, treated plants lost pigmentation and stems and leaves turned white (Figure 4). Pigmentation loss persisted over the 17day treatment period for plants in the mesocosms treated with 500- and 1000mg lime $\mathrm{L}^{-1}$. Similar symptoms were observed for plants treated with $250 \mathrm{mg}$ lime $\mathrm{L}^{-1}$. Blanched plant tissue did not recover after treatment and did not regain pigment coloration. However, stem and leaf regrowth occurred as new auxiliary buds during the second week of lime treatment for plants treated with 250-mg lime $\mathrm{L}^{-1}$ (Figure 4).

Lime application resulted in suppressed plant growth and lower mean shoot and root biomass relative to the control (Figure 3). Mean shoot biomass was greatest in the control, intermediate in the mesocosm treated with 250-mg lime $\mathrm{L}^{-1}$, and lowest for the mesocosm treated with 500- and 1000-mg lime $\mathrm{L}^{-1}$. However, mean shoot biomass did not decline appreciably in treated mesocosms relative to shoot biomass estimates at the time of treatment. Mean root biomass was significantly lower in treated versus control mesocosms; however, no significant differences were observed in mean root biomass between treated mesocosms (ANOVA; SAS 1994).

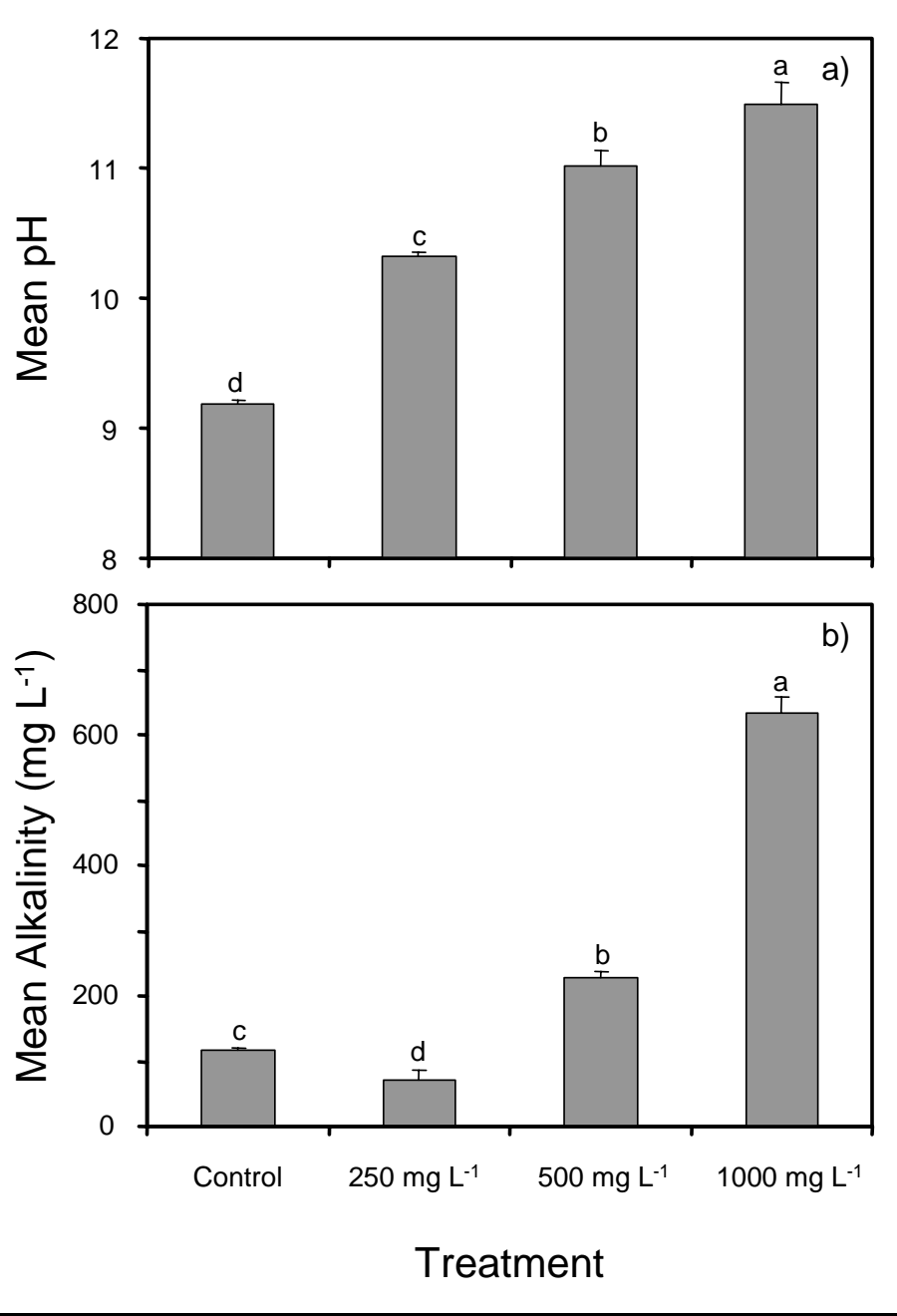

Figure 2. Variations in mean $\mathrm{pH}$ and alkalinity $(\mathrm{n}=10)$ over the lime application period (17 days). Vertical lines represent 1 standard error. Letters indicate significant differences at the 5-percent level or less (ANOVA; SAS 1994) 


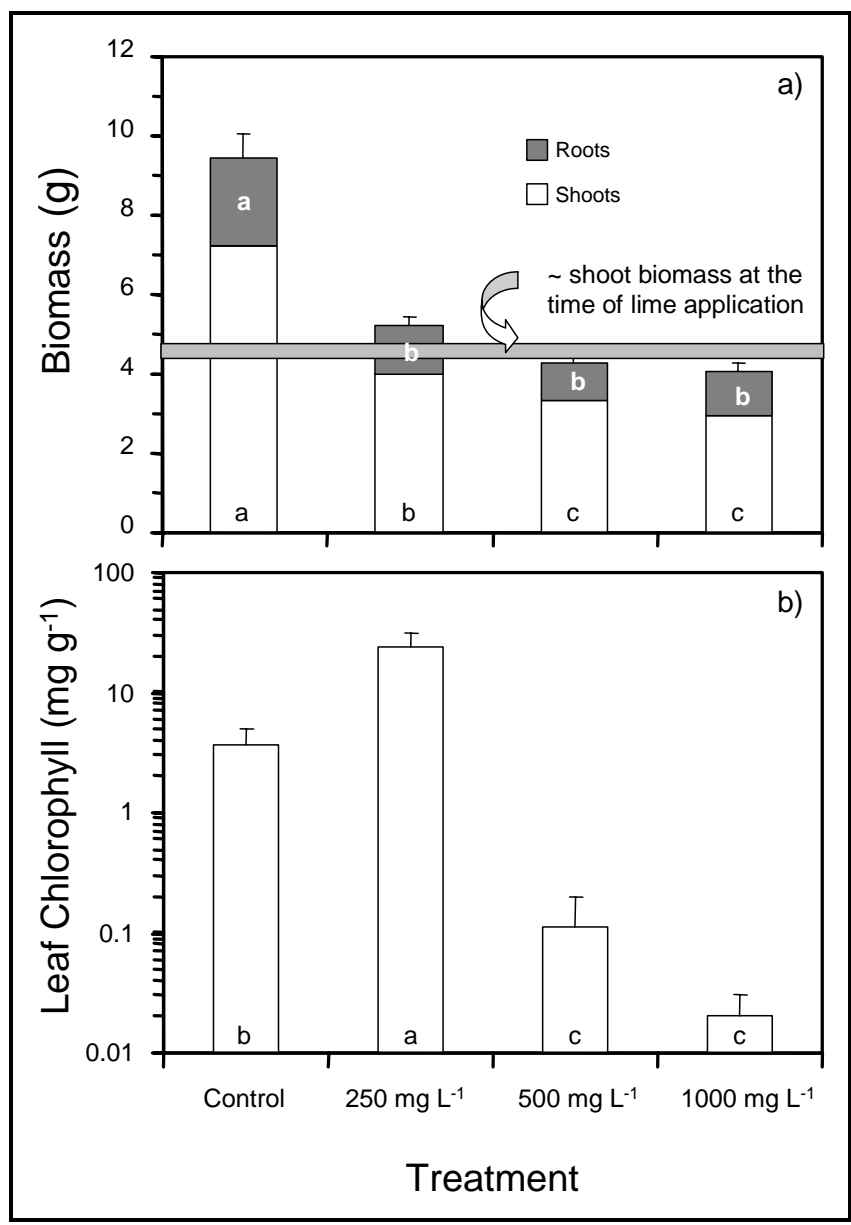

Figure 3. Variations in (a) mean shoot and root biomass, and (b) mean leaf chlorophyll (note logarithmic scale) for plants grown in control and treated mesocosms. Horizontal bar represents the approximate shoot biomass at the time of lime application. Vertical lines represent 1 standard error. Letters indicate significant differences at the 5-percent level or less (ANOVA; SAS 1994)
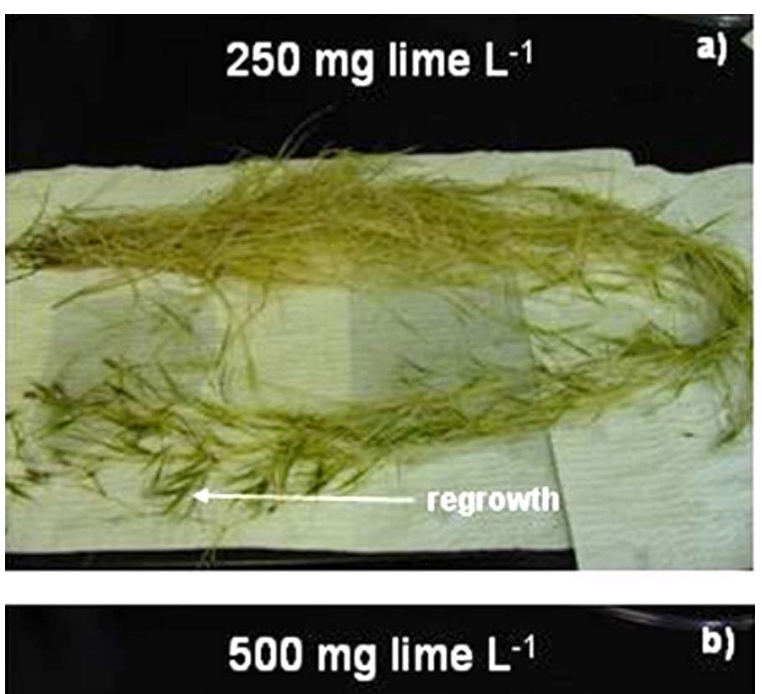

Figure 4. Plant appearance shortly after harvesting from the $250-\mathrm{mg}$ lime $\mathrm{L}^{-1}$ and 500-mg lime $\mathrm{L}^{-1}$ treated mesocosms (note the regrowth in panel (a) versus the blanched leaf and stem appearance in panel (b))

Corroborating observed pigment loss symptoms for plants in the treated mesocosms, mean leaf chlorophyll was significantly lower in mesocosms treated with 500 and $1000 \mathrm{mg}$ lime $\mathrm{L}^{-1}$ by 1 to 2 orders of magnitude and nearly undetectable versus control mean leaf chlorophyll (Figure 3). In contrast, mean leaf chlorophyll was greatest for plants treated with $250-\mathrm{mg} \mathrm{lime} \mathrm{L}^{-1}$, reflecting the apparent auxiliary bud regrowth that occurred in this mesocosm.

Results indicated that experimental lime application suppressed further plant growth relative to the control. Growth suppression appeared to be associated with a rise in $\mathrm{pH}$ above 10.5, suggesting that lime-induced $\mathrm{pH}$ increases were impacting growth by limiting free carbon dioxide and bicarbonate availability for photosynthesis (Chambers et al. 2001). It was notable that plants subjected to the 
250-mg lime $\mathrm{L}^{-1}$ treatment exhibited visual pigment loss and growth stress but then recovered and displayed regrowth toward the end of the study. This pattern coincided with a drop in $\mathrm{pH}$ to less than 10.5 during the second week of treatment, suggesting increased inorganic carbon availability for growth. The greater concentrations of lime that were added to the other mesocosms maintained the $\mathrm{pH}$ above 10.5 and plant regrowth did not occur.

Reasons for pigment loss at the higher $\mathrm{pH}$ levels are not currently known. If inorganic carbon limitation is the mode of action suppressing plant growth, chlorophyll synthesis could also be inhibited at high $\mathrm{pH}$ levels. It also appeared that pigmentation was not restored in plant tissues stressed by high $\mathrm{pH}$, and that any recovery in growth was in the form of new tissue development, based on observations of plant growth in the mesocosm treated with $250-\mathrm{mg}_{\text {lime }} \mathrm{L}^{-1}$.

Although growth was stressed, plant senescence was not observed during the study. Chambers et al. (2001) reported a similar finding for plants treated with up to $1000 \mathrm{mg} \mathrm{L}^{-1}$. The exposure time to lime and high $\mathrm{pH}$ is probably a critical factor in plant success or death and needs to be investigated. For instance, exposure times of longer than 17 days at $\mathrm{pH}$ levels greater than 10.5 may have been required to cause actual plant death in this study. The effect of lime application during different phases of the life cycle also needs to be examined. Lime applied to systems earlier in the plant's life cycle may be more effective in stressing growth and reproductive persistence than later in the life cycle. Finally, if $\mathrm{pH}$ is a factor in suppressing plant growth via inorganic carbon limitation, the impacts of lime application and high $\mathrm{pH}$ on other ecological components such as invertebrates and fish need to be evaluated. The high $\mathrm{pH}$ and alkalinity concentrations created in the mesocosm study by a lime application of $1000 \mathrm{mg} \mathrm{L}^{-1}$ would severely impact aquatic communities and should not be considered as practical for aquatic macrophyte control.

ACKNOWLEDGMENTS: Ms. Laura Pommier of ASI (Analytical Services, Inc.) is gratefully acknowledged for conducting analytical and biomass determinations.

POINTS OF CONTACT: This technical note was written by Mr. William F. James and Mr. Harry L. Eakin of the Eau Galle Aquatic Ecology Laboratory, Environmental Laboratory (EL), U.S. Army Engineer Research and Development Center (ERDC), and Dr. John W. Barko, EL, ERDC. For additional information, contact the manager of the Aquatic Plant Control Research Program, Mr. Robert C. Gunkel (601-634-3722, Robert.C.Gunkel@,erdc.usace.army.mil). This technical note should be cited as follows:

James, W. F., Eakin, H. L., and Barko, J. W. (2005). "Experimental effects of lime application on aquatic macrophytes: 1 . Growth response versus concentration," APCRP Technical Notes Collection (ERDC/TN APCRP-EA-10), U.S. Army Engineer Research and Development Center, Vicksburg, MS. http://el.erdc.usace.army.mil/aqua/aqua.html.

\section{REFERENCES:}

American Public Health Association (APHA). (1998). "Standard methods for the examination of water and wastewater," $20^{\text {th }}$ ed., American Public Health Association, Washington, DC.

Babin, J., Prepas, E. E., and Zhang, Y. (1992). “Application of lime and alum to stormwater retention lakes to improve water quality,” Wat. Pollut. Res. J. Canada 27, 365-381. 
Chambers, P. A., Prepas, E. E., Ferguson, M. E., Serediak, M., Guy, M., and Holst, M. (2001). "The effects of lime addition on aquatic macrophytes in hard water: In situ and microcosm experiments,” Freshwat. Biol. 46, 1121-1138.

Prepas, E. E., Murphy, T. P., Crosby, J. M., Walty, D. T., Lim, J. T., Babin, J., and Chambers, P. (1990). “ Reduction of phosphorus and chlorophyll A concentrations following $\mathrm{CaCO}_{3}$ and $\mathrm{Ca}(\mathrm{OH})_{2}$ additions to hypereutrophic Figure 8 Lake, Alberta,” Environ. Sci. Tech. 24, 1252-1258.

Prepas, E. E., Pinel-Alloul, B., Chambers, P., Murphy, T. P., Reedyk, S., Sandland, G., and Serediak, M. (2001). "Lime treatment and its effect on the chemistry and biota of hardwater eutrophic lakes," Freshwat. Biol. 46, 1049-1060.

Rattei, M. (2004). “Lime slurry-An innovative management tool for aquatic plants,” Biol. Restoration 22, 147-148.

Reedyk, S., Prepas, E. E., and Chambers, P. A. (2001). "Effects of single $\mathrm{Ca}(\mathrm{OH})_{2}$ doses on phosphorus concentration and macrophyte biomass of two boreal eutrophic lakes over 2 years,” Freshwat. Biol. 46, 1076-1087.

Statistical Analysis System (SAS). (1994). “SAS/STAT User’s Guide, version 6,” $4^{\text {th }}$ ed., SAS Institute, Cary, NC.

Welschmeyer, N. A. (1994). "Fluorometric analysis of chlorophyll A in the presence of chlorophyll B and pheopigments,” Limnol. Oceanogr. 39, 1985-1992.

NOTE: The contents of this technical note are not to be used for advertising, publication, or promotional purposes. Citation of trade names does not constitute an official endorsement or approval of the use of such products. 